\title{
THE INFLUENCE OF LMX DIMENSIONS ON CERTAIN DIMENSIONS OF ORGANIZATIONAL CULTURE IN SERBIAN COMPANIES
}

\author{
UDC: 005(497.11) \\ Original Scientific Paper \\ Jelena VUKONJANSKI ${ }^{1}$, Milan NIKOLIĆ ${ }^{2}$, Edit TEREK $^{3}$, Dragica IVIN $^{2}$, \\ Bojana GLIGOROVIĆ ${ }^{1}$ \\ ${ }^{1}$ Republic of Serbia \\ ${ }^{2}$ University of Novi Sad, Technical faculty “Mihajlo Pupin” Zrenjanin, 23000 Zrenjanin, Đure Đakovića bb, \\ Republic of Serbia \\ ${ }^{3}$ University of Novi Sad, Technical faculty “Mihajlo Pupin” Zrenjanin, 23000 Zrenjanin, Đure Đakovića bb, \\ Republic of Serbia \\ E-mail: terekedita@gmail.com
}

Paper received: 20.10.2015.; Paper accepted: 02.11.2015.

\begin{abstract}
The paper presents the research results related to LMX influence dimensions (Leader Member Exchange)on certain dimensions of organizational culture (Future Orientation, Power Distance, Human Orientation and Performance Orientation). The research was carried out by a survey and the examinees were middle level managers, employed in Serbian companies. The answers of totally $N=400$ interviewed managers from 129 companies were collected. The results confirmed that a high level of LMX dimensions positively affects the increase of certain dimensions of organizational culture. In addition, all correlations between LMX dimensions and the analyzed dimensions of organizational culture were positive and statistically significant except the correlations with Power Distance in which correlation coefficients were negative but statistically significant. Leaders must be aware of these phenomena: they have the opportunity to increase the level of organizational culture and business performance in their companies by their own behaviour and the steps they take.
\end{abstract}

Keywords: LMX, organizational culture, GLOBE project, companies in Serbia.

\section{INTRODUCTION}

Leader Member Exchange (LMX) theory has been a focus of numerous authors (Goertzen \& Fritz, 2004; Graen \& Uhl-Bien, 1991; Ferris et al., 1991; Pellegrini \& Scandura, 2006). Through many researches and studies that have been in progress for more than 25 years, LMX has evolved into a general estimation of a work relationship between leaders and members measured by the extent of their mutual confidence, loyalty, understanding and support (Keup, 2000).

All leaders should be trained to be able to develop a quality relationship with their subordinates (Graen \& Uhl-Bien 1995). Numerous researches which represent the benefits of a very leadermember relationship point at this (Graen et al., 1973; Scandura \& Graen, 1984; Crouch \& Yetton,
1988; Erdogan et al., 2006; Pellegrini \& Scandura, 2006). In addition, many studies show that a quality leader-member relationship significantly affects various organizational variables (Scandura \& Graen, 1984; Scandura et al., 1986; Stepina et al., 1991; Ferris et al., 1991; Dunegan et al., 1992; Judge \& Ferris, 1993; Erdogan \& Enders, 2007). Besides, there are lots of researches which confirm statistically significant relationship between dimensions of organizational culture and LMX (Erdogan et al., 2006; Pellegrini \& Scandura, 2006; Botero \& Van Dyne, 2009).

According to Hofstede (Hofsede, 1980; Hofsede 2001), culture is described by symbols, heroes, ceremonies and values. The author also points at the fact that different national cultures influence different management practice, values, expectations and behaviour of managers. Hofstede 
(Hofsede, 1991) considers culture as a mind software which distinguishes the members of one organization from the members of the other. According to House et al. (House et al., 1997), culture is a collectively oriented phenomenon related to common meaning and cultural norms are manifested in the form of artefacts. Organizational culture is connected to numerous organizational outcomes in a company (House et al., 2004).

Denison (Denision, 1996) noticed the following fundamental dilemma in the literature of organizational culture: should a theory put an accent on examining the influence of individuals on organizational culture or vice versa? The theory of micro level equalises organizational culture with perception of employees in organizations, whereby their perceptions are organizational and they also must be based on common stimulus that exists in the organization. Organizational culture is partially developed as an answer to the stimulus which is commonly experienced by organizational members. According to Denison (Denision, 1996), a concrete source or a common element includes a leadership practice which is being used in an organization and becomes a manifesto in institutional structure and its rules.

In this paper, the influence of LMX dimensions on the level of some dimensions of organizational culture, according to GLOBE project (The Global Leadership and Organizational Behavior Effectiveness Research Project), in the companies in Serbia is determined. The following dimensions of organizational culture are studied in the paper: Future Orientation, Power Distance, Human Orientation and Performance Orientation. The mentioned dimensions are chosen because they probably best represent total business orientation and perspective of the company. The results of the research, discussion and conclusions are also presented.

\section{THEORY AND HYPOTHESES}

\section{Leader-member exchange}

Leader Member Exchange (LMX) theory is a leadership theory which describes a quality of the relationship between superiors and their subordinates (Dansereau et al. 1975). This theory is the most widely researched leadership theory (Goertzen \& Fritz, 2004) and its quality is measured by mutual trust between superiors and members (Seabright et al., 1992). The result of trust in leader-member relationship brings numerous benefits (Graen \& Uhl-Bien, 1991). The quality of LMX is important because it is relied on satisfaction of employees, their promotion, performance relations, organizational and civic behaviour and communication (Gerstner \& Day 1997; Liden et al., 1997). The group members with high LMX share mutual trust, respect, mutual influence, loyalty, connection, responsibility towards a leader (Graen \& Uhl-Bien, 1995). The quality of LMX is recognized as a mutual support and exchange of formal and informal rewards (Dienesch \& Liden 1986).

\section{Organizational culture}

Organizational culture is deeply rooted in every organization. Every organization has invisible qualities, specific style and character or a specific way of doing business. Even when it is bad, organizational culture exists. Probably the most frequent definition of organizational culture is: "It is how we work here" (Bower, 1966; Deal \& Kennedy, 1982; Martin, 2006). Such an opinion is more powerful than some regulations of a formal system or even a person. Invisible qualities determine how successful an organization is. The best understanding of organizational culture is that it exists on several levels, so individuals must undertand and manage organizational culture at a higher level. There are, of course, many definitions but it can be said that organizational culture assumes the achieved knowledge and experience which an individual uses in the development process of his/her organizational behaviour.

Successful managers should affect the employees and therefore organizational culture unites values and attitudes of employees in a company (Weihrich \& Koontz, 1998). Great insecurity in an organization often endangeres its achievements. For this reason, a frequent topic of organizational researches is reducing insecurity as a way od establishing control over organization' destiny (Thompson, 1967).

On the grounds of the mentioned above the following hypothesis is derived:

H1: A higher quality of LMX dimension positively affects certain dimensions of organizational culture in Serbian companies.

H2: The influence of LMX dimensions on certain dimensions of organizational culture is statistically significant. 


\section{METHOD}

\section{Survey instruments (measures)}

A questionnaire LMX-MDM (Liden \& Maslyn, 1998) was used as an instrument of exchange between leaders and members. The questionnaire is consisted of 12 items that measure four dimensions: affect, loyalty, contribution, and professional respect. Item responses were scaled from 1 (strongly disagree) to 5 (strongly agree).

An instrument from GLOBE project for measuring organizational culture (House et al. 1999, 2002, 2004) was used in this paper. The questionnaire is consisted of 34 items that measure 9 dimensions: Uncertainty Avoidance, Future oriented, Power Distance, Collectivism I (Institutional), Human Orientation, Performance Orientation, Collectivism II (In-Group), Gender Egalitarianism, Assertiveness. The examinees responded by marking the values on the scale from 1 to 7 . The emphasis was on the dimensions - Future Orientation, Power Distance, Human Orientation and Performance Orientation.

\section{Participants and data collection}

The research was carried out in Serbian companies. It was realized by means of questionnaire - the examinees (middle management) completed the questionnaire. The survey was conducted by using interviews with respondents. A total of $\mathrm{N}=400$ middle managers from 129 companies completed the questionnaire.

\section{RESULTS}

Descriptive statistics of LMX dimensions and certain dimensions of organizational culture is presented in Table 1. The Table presents, among the others, the names of dimensions, a short name for every dimension (later used in the text), mean values and standard deviations of all items and dimensions, as well as Cronbach's alpha for every dimension. The values of Cronbach's alpha range in the interval from $\alpha=0.750$ to $\alpha=0.930$.

Within descriptive statistics we observed the behaviour of certain dimensions of organizational culture for low and high LMX (for every dimension of LMX).The results of these calculations that support $\mathrm{H} 1$ are presented in tabeli 2.

Table 1: Descriptive statistics for all dimensions

\begin{tabular}{|l|c|c|c|c|c|c|c|}
\hline Dimensions & Abbreviations & N & Min. & Max. & Mean & Std. Deviation & $\boldsymbol{\alpha}$ \\
\hline Affect & LMX1 & 400 & 1.00 & 5.00 & 3.6308 & .93783 & .774 \\
\hline Loyalty & LMX2 & 400 & 1.00 & 5.00 & 2.9917 & 1.14352 & .883 \\
\hline Contribution & LMX3 & 400 & 1.00 & 5.00 & 3.6492 & .92671 & .750 \\
\hline Professional Respect & LMX4 & 400 & 1.00 & 5.00 & 3.5142 & 1.15943 & .903 \\
\hline Future Orientation & FO & 400 & 1.00 & 7.00 & 3.8225 & 1.61530 & .817 \\
\hline Power Distance & PD & 400 & 1.00 & 7.00 & 4.3233 & 1.59971 & .801 \\
\hline Human Orientation & HO & 400 & 1.00 & 7.00 & 4.3556 & 1.59826 & .930 \\
\hline Performance Orientation & PO & 400 & 1.00 & 7.00 & 4.1412 & 1.40266 & .806 \\
\hline & Valid N & 400 & & & & & \\
\hline
\end{tabular}

Table 2: Average values of dimensions for high and low LMX (from LMX1 to LMX4)

\begin{tabular}{|c|c|c|c|c|c|c|c|c|}
\hline & \multicolumn{2}{|c|}{ LMX1 } & \multicolumn{2}{c|}{ LMX2 } & \multicolumn{2}{c|}{ LMX3 } & \multicolumn{2}{c|}{ LMX4 } \\
\hline & Low & High & Low & High & Low & High & Low & High \\
\hline FO & 3.3700 & 4.2750 & 3.3500 & 4.2950 & 3.5600 & 4.0850 & 3.1983 & 4.4467 \\
\hline PD & 4.7850 & 3.8617 & 4.8383 & 3.8083 & 4.6483 & 3.9983 & 4.8083 & 3.8383 \\
\hline HO & 3.8475 & 4.8637 & 3.7412 & 4.9700 & 4.0750 & 4.6363 & 3.8112 & 4.9000 \\
\hline PO & 3.6588 & 4.6237 & 3.5700 & 4.7125 & 3.8750 & 4.4075 & 3.5175 & 4.7650 \\
\hline
\end{tabular}

Table 3: Pearson coefficients of correlation between dimensions of LMX and organizational culture

\begin{tabular}{|l|c|c|c|c|}
\hline & LMX1 & LMX2 & LMX3 & LMX4 \\
\hline FO & $.341^{* *}$ & $.275^{* *}$ & $.151^{* *}$ & $.417^{* *}$ \\
\hline PD & $-.417^{* *}$ & $-.315^{* *}$ & $-.122^{* *}$ & $-.325^{* *}$ \\
\hline HO & $.343^{* *}$ & $.326^{* *}$ & $.191^{* *}$ & $.346^{* *}$ \\
\hline PO & $.465^{* * *}$ & $.406^{* *}$ & $.239^{* * *}$ & $.526^{* *}$ \\
\hline
\end{tabular}

$* \mathrm{p}<0.05 ; * * \mathrm{p}<0.01$ 
By means of correlation analysis mutual dependences of LMX dimensions and the analyzed dimensions of organizational culture are confirmed. The research results of statistically significant relations that support $\mathrm{H} 2$ are presented in Table 3.

\section{DISCUSSION}

Descriptive statistics (Table 1) shows that all LMX dimensions have similar mean values except Loyalty - LMX2, which is considerably lower (2.9917). On the basis of this fact can be concluded that the level of loyalty between leaders and their members in Serbian companies is low. Loyalty is developed over time but, unfortunately, in Serbian companies the changes of personnel /staff are frequent. Besides, a high value of the organizational culture dimension should be taken into account - Power Distance - PD (4.3233) on the basis of it can be concluded that the leaders neglect the importance of loyalty in leader-member relationship because loyalty replaces the power which the leaders have in relation to the members. On the contrary, the values of other dimensions, especially Affect - LMX1 (3.6308) indicate that middle managers in Serbian companies recognize and positively evaluate actions and character of leaders which is in harmony with the value of the dimension - Loyalty - LMX2. Unfortunately, the same support is not returned by leaders.

Serbia is a country with high Power Distance (Vukonjanski et al., 2012; Nikolić et al., 2014). It is confirmed by the value of Power Distance - PD (4.3233) dimension. In the organizations with high Power Distance there is a clear difference between those who have power and status from those without these qualities. Employees are expected to be obedient and submissive.Besides, information are controlled and only few people have an access to resources and money, so promotions and rewards mostly depend on employees status (House et al., 2004). In comparison to the results of the previous research (Vukonjanski et al., 2012; Nikolić et al., 2014), it can be noticed that Power Distance is lower than before. The results represent a step forward in positive direction. Another positive result is the increased value of organizational culture dimension Performance Orientation - PO (4.1412). This characteristic shows that employees in Srbian companies are increasingly encouraged and rewarded for better performances and excellence than before. However, in comparison to the previous research (Vukonjanski et al., 2012; Nikolić et al., 2014), the values of the dimensions Future Orientation - FO and Human Orientation - HO are lower. During the period in which Serbia suffered from great political and economic problems management, in majority of organizations, was short - term oriented. Considerable changes which happened in Serbia, both political and economic, affected leaders and managers so they less understood orientation towards future as an important aspect of organizational culture and a pre-condition for achieving global competitiveness. Reduced values of these dimensions can be explained as a lower readiness for changes. As a result of all these issues we can observe a lower degree of individual involvement in organizations related to planning and decisions on future investments. In addition, in Serbian companies, individuals who are fair, friendly, generous, kind and caring are not enough respected and appreciated. In short, this situation can be understood as it follows: there is a tendency in Serbian companies to short-term thinking, neglection of the future of the company and employees, and the focus is on current performances. Reduced Power Distance is perhaps an ostensibly good result which in fact does not bring a qualitative change but is only the means that leaders use to make profit and improve performances without strategies for the future and sincere care for employees.

High values of all LMX dimensions of the relation (High LMX) are followed by high values of organizational culture dimensions, except Power Distance dimension - PD, where the values are lower in high LMX relation. In a sub - sample with high values of LMX dimensions middle managers have greater support from their leaders and better chances to make their job more versatile and innovative. In the situation of high values of LMX dimensions the use of legitimate power is present as well as reduced privilleges. In a subsample with high values of LMX dimensions welbeing of the others is promoted as well as leadership which is characterized by support and respect of subordinates. There is also understanding and acceptance of organizational changes related to all employees in greater extent than in a sub-sample with lower values of LMX dimensions (Low LMX). High values of LMX dimensions surely positively affect all analyzed dimensions of organizational culture as expected.

All correlations of the relation LMX dimensions and organizational culture dimensions are significantly and positively associated except Power Distance - PD dimension in which 
correlation coefficients are negative but statistically significant. The greatest influence on the observed dimensions of organizational culture has Professional Respect - LMX4 dimension in the cases in which each member of the dyad has built a reputation, within and/or outside the organization, of excelling at his or her line of work (Liden \& Maslyn, 1998). It most affects Performance Orientation - PO $\left(.526^{* *}\right)$ dimension of organizational culture. Top professional leaders will surely tend to achieve high performances. At the same time, out of all LMX dimensions Professional Respect - LMX4 has the strongest correlation with Future Orientation - FO $\left(.417^{* *}\right)$ dimension. Professional Respect - LMX4 contributes to employees to better understand and respect their leaders so they can more easily accept organizational changes which are crucial for orientation towards the future. If we want to consider the influences of the dimension Professional Respect - LMX4 in detail, we have to say that it least affects Power Distance - PD $\left(.325^{* *}\right)$ dimension. Social, economic and political stratification is characteristic for the countries with high value of Power Distance dimension and those who have power expect and accept obedience (Javidan et al., 2006). Professionalism of leaders considerably contributes to future orientation and performances, however, their professionalism less affects -although positively- the orientation towards people and reduction of Power Distance. Professional excellence is greater indicator of knowledge and professionalism than humanity. On the other hand, professionalism enables better understanding of employees, their tasks and problems and gives leaders higher self-confidence, so it helps them to reduce the need for increasing Power Distance.

The least influence on organizational culture dimensions has Contribution - LMX3 dimension.In the companies in Serbia, employees are willing to work more, even outside their tasks in order to achieve goals, but on the other hand it is more probable that they work more because they think it is the part of their job or they do not see other opportunities. This phenomenon was confirmed in the reference (Liden \& Maslyn, 1998). At the same time, the strongest correlations with LMX dimensions, out of the analyzed, has Performance Orientation - PO. High LMX considerably increases motivation of $\mathrm{HR}$ and gives them strength to work more and better. Accordingly, high LMX dimensions most directly and fastest affect employees quality of work and achieving good results. However, there is a question: how does, in such conditions, the dimension Contribution - LMX3 (which has a common denomonator with Performance Orientation - PO, willingness for additional work), have the least influence on the analyzed dimensions of organizational culture? This is a one-sided process: high LMX motivates employees to work more and this affects the performances, but their willingness to work more because of the leader, does not mean that this is the most significant way for improving organizational culture. Greater willingness of employees to invest additional efforts represents a consequence of quality LMX but it is not, per se, a driver of further, positive changes of organizational culture. Besides, it must not be neglected that the influence of Contribution LMX3 dimension on organizational culture dimensions exists but it is only expressed by weaker correlations than in cases of other LMX dimensions.

\section{CONCLUSION}

The research results show that there has been a change in Serbian companies related to cultural process compared to the previous research (Vukonjanski et al., 2012; Nikolić et al., 2014). Some of the changes are for better, for example, reduction of Power Distance dimension and increase of Performance Orientation dimension. This is of special significance because it was confirmed that Serbia was a country with exceptionally high Power Distance according to the research carried out by Hofstede (Hofsede, 1980; Hofsede, 2001), and since that time the value of the dimension has not been reduced. Reduction of Power Distance dimension possibly indicates some changes for better in the society and in minds of managers in Serbia. Nevertheless, there is room for caution: reduced Power Distance may be only means for achieving good business results. Reduced values of the dimensions Future Orientation - FO and Human Orientation - HO point at this conclusion. However, for final results on these issues it is necessary to do a wider research that will include all nine dimensions of GLOBE organizational culture dimensions. It was not the objective of this paper.

A high level of LMX dimensions (High LMX) has no doubt positive influence on the increase of the level of the analyzed organizational culture dimensions (probably of other organizational culture dimensions as well). The hypothesis $\mathrm{H} 1$ is confirmed by this result. Identification of these associations between the dimensions of LMX 
practice and perceptions of organizational culture dimensions can help companies to determine their culture and identify potential instruments for organizational changes and improvement of their organizational culture (Vukonjanski et al., 2012). Besides, all correlations between LMX dimensions and the analyzes dimensions of organizational culture are positive and statistically significant except the correlation with Power Distance - PD, in which the coefficients are negative but statistically significant. This result was expected and thus the hypothesis $\mathrm{H} 2$ was confirmed.

The results point at significance and influence of LMX dimensions on organizational culture. If we take into account that organizational culture affects all business processes within a company it is clear in what extent LMX is important for total functioning of the company. Leaders and manager have to be aware of these relations and their role in the relations. This is their main role. They can, with small changes in their behaviour and activities, significantly increase the level of organizational culture and business in their companies. For example, the research has shown that loyalty of leaders represents the weakest ring in LMX relations. It could be the starting point of our leaders on the road that assumes greater respect of their subordinates, motivation of employees based on their own example, fair and honest relationship towards all employed people in the company. It seems easy, but perhaps it is not...?

\section{REFERENCES}

Botero, I.C., \& Van Dyne, L. (2009). Employee Voice Behavior: Interactive Effects of LMX and Power Distance in the United States and Colombia. Management Communication Quarterly, 23(1), 84104.

Bower, M. (1966). The Will to Manage: Corporate Success Through Programmed Management. New York: McGraw-Hill.

Crouch, A., \& Yetton, P. (1988). Manager-subordinate dyads: Relationships among task and social contact manager friendliness, and subordinate performance in management groups. Organizational Behavior and Human Decision Processes, 41, 65-82.

Dansereau, F., Graen, G.B., \& Haga, W. (1975). A vertical dyad linkage approach to leadership in formal organizations. Organizational Behavior and Human Performance, 13, 46-78.

Deal T.E., \& Kennedy, A.A. (1982). Corporate Cultures: The Rites and Rituals of Corporate Life. Harmondsworth: Penguin Books.

Denison, D.R. (1996). What is the difference between organizational culture and organizational climate? A native's point of view on a decade of paradigm wars. Academy of Management Review, 21(3), 619-654.
Dienesch, R.M., \& Liden, R.C. (1986). Leader-member exchange model of leadership: A critique and further development. Academy of Management Review, 11(3), 618-634.

Dunegan, K.J., Duchon, D., \& Uhl-Bien, M. (1992). Examining the link between leader-member exchange and subordinate performance: the role of task analyzability and variety as moderators. Journal of Management, 18(1), 59-76.

Erdogan, B., \& Enders, J. (2007). Support from the top: supervisors' perceived organizational support as a moderator of leader-member exchange to satisfaction and performance relationships. Journal of Applied Psychology, 92(2), 321-330.

Erdogan, B., Liden, R.C., \& Kraimer, M.L. (2006). Justice and leader-member exchange: The moderating role of organizational culture. Academy of Management Journal, 49(2), 395-406.

Ferris, G.R., Judge, T.A., Chachere, J.G., \& Liden, R.C. (1991). The age context of performance evaluation decisions. Psychology and Aging, 6(4), 616 - 622.

Gerstner, C.R., \& Day, D.V. (1997). Meta-analytic review of leader-member exchange theory: Correlates and construct issues. Journal of Applied Psychology, 82(6), 827-844.

Goertzen, B.J., \& Fritz, S. (2004). Does sex of dyad members really matter? Journal of Leadership Education, 3(1), 1-18.

Graen, G.B., Orris, D., \& Johnson, T. (1973). Role assimilation processes in a complex organization. Journal of Vocational Behavior, 3, 395-420.

Graen, G.B., \& Uhl-Bien, M. (1991). The transformation of professionals into self-managing and partially self-designing contributions: Toward a theory of leader-making. Journal of Management Systems, 3(3), 33-48.

Graen, G.B., \& Uhl-Bien, M. (1995). Relationshipbased approach to leadership: Development of leader member exchange (LMX) theory of leadership over 25 years, applying a multilevel multidomain perspective. Leadership Quarterly, 6, 219-247.

Hofstede, G. (1980). Culture's Consequences International Differences in Work-Related Values, Abridged Edition, Sage: Newbury Park.

Hofstede, G. (1991). Cultures and organizations: software of the mind. New York: McGraw-Hill.

Hofstede, G. (2001). Culture's Consequences, Comparing Values, Behaviors, Institutions, and Organizations Across Nations. Thousand Oaks CA: Sage Publications.

House, R. J., Hanges, P. J., Ruiz-Quintanilla, S. A., Dorfman, P. W., Falkus, S. A. \& Ashkanasy, N. M. (1999). Cultural influences on leadership and organizations: Project Globe. In W. H. Mobley, M. J. Gessner and V. Arnold (Ed.), Advances in Global Leadership 2 ed. (171-233) Bingley, UK: Emerald Group Publishing Ltd.

House, R., Wright, N.S., \& Aditya, R.N. (1997). Crosscultural research on organizational leadership: A critical analysis and proposed theory. In P.C. Early, M. Erez (Eds.) (535-625). New Perspectives on 
International Industrial/Organizational Psychology San Francisco, CA: Lexington Press.

House, R.J., Hanges, P.J., Javidan, M., Dorfman, P.W., \& Gupta. V. (2004). Leadership, culture, and organizations: The GLOBE study of 62 societies. Thousand Oaks, CA: Sage.

House, R.J., Javidan, M., Hanges, P., \& Dorfman, P. (2002). Understanding Cultures and Implicit Leadership Theories Across the Globe: An Introduction to Project GLOBE. Journal of World Business, 37(1), 3-10.

Javidan, M., Dorfman, P.W., Sully de Luque, M.F. \& House, R.J. (2006). In the eye of the beholder: cross cultural lessons in leadership from project GLOBE. Academy of Management Perspectives, 20(1), 6790.

Judge, T.A., \& Ferris, G.R. (1993). Social context of performance evaluation decisions. Academy of Management Journal, 36, 80-105.

Keup, L. C. (2000). A network of working relationships and its influence on individual job outcomes. Ph.D. dissertation. Canada: The University of Manitoba (Canada).

Liden, R. C., \& Maslyn, J. M. (1998). Multidimensionality of leader- member exchange: An empirical assessment through scale development. Journal of Management, 24, 43-72.

Liden, R.C., Sparrowe, R.T., \& Wayne, S.J. (1997). Leader-member exchange theory. The past and potential for the future. Research in Personnel and Human Resources Management, 15, 47-119.

Martin, M.J. (2006). „That's the Way We Do Things Around Here": An Overview of Organizational Culture. Electronic Journal of Academic and Special Librarianship, 7(1). Retrieved from: http://southernlibrarianship.icaap.org/content/v07n0 1/martin_m01.htm

Nikolić. M., Vukonjanski, J., Nedeljković, M., Hadžić, O., \& Terek, E. (2014). The relationship between communication satisfaction, emotional intelligence and the GLOBE organizational culture dimensions of middle managers in Serbian organizations. Journal for East European Management Studies, 19(4), 387-412.
Pellegrini, E.K., \& Scandura, T.A. (2006). LeaderMember Exchange (LMX), Paternalism, and Delegation in the Turkish Business Culture: An Empirical Investigation. Journal of International Business Studies, 37(2), 264-279.

Scandura, T.A., Graen, G.B. (1984). Moderating effects of initial leader-member exchange status on the effects of a leadership intervention. Journal of Applied Psychology, 69(3), 428-436.

Scandura, T.A., Graen, G.B., \& Novak, M.A. (1986). When managers decide not to decide autocratically. Journal of Applied Psychology, 71(4), 579-584.

Seabright, M.A., Leventhal, D.A., \& Fichman, M. (1992). Role of individual attachments to the dissolution of inter-organisational relationships. Academy of Management Journal, 35, 22-60.

Stepina, L.P., Perrewe, P.L., \& Hassell, B.L. (1991). A comparative test of the independent effects of interpersonal, task, and reward domains on personal and organizational outcomes. Journal of Social Behavior and Personality, 6(1), 93-104.

Thompson, J.D. (1967). Organizations in action. New York: McGraw-Hill.

Vukonjanski, J., Nikolić, M., Hadžić, O., Terek, E., \& Nedeljković, M. (2012). Relationship between GLOBE organizational culture dimensions, job satisfaction and leader-member exchange in Serbian organizations. Journal for East European Management Studies, 17(3), 333-368.

Weihrich, H., \& Koontz, H. (1998). Management. 11th ed. Zagreb: Mate.

\section{ACKNOWLEDGMENT}

This paper is a part of the research project "The impact of organizational culture and leadership on some organizational and business performances in companies in Serbia", which is funded by the Provincial Secretariat for Science and Technological Development within the action "Right for first chance". 